\title{
KISAH NABI ADAM DI DALAM NASKAH INCUNG INI ASAN PULUNG DARI KERINCI
}

\section{THE STORY OF ADAM PROPHET IN THE INCUNG MANUSCRIPT “INI ASAN PULUNG” FROM KERINCI}

\author{
Hafiful Hadi Sunliensyar ${ }^{1}$ \\ ${ }^{1}$ Masyarakat Pernaskahan Nusantara (MANASSA), Indonesia \\ h.hadi@mail.ugm.ac.id
}

DOI: 10.31291/jlka.v19.i2.901

Diterima: 15 September 2021; Direvisi: 15 Desember 2021;

Diterbitkan: 31 Desember 2021

\begin{abstract}
The religious manuscripts found in Kerinci were written using Jawi script (Arab-Melayu) generally. However, the Incung manuscript that was found as the sacred heirloom collection of Depati Anum Muncak Alam from Dusun Sungai Tutung, indicated something different. This Incung manuscript is a religious manuscript that narrates the Adam prophet's story. This Incung manuscript is titled Ini Asan Pulung with code EAP117-44-1-6. The problem in this study is how the narration of Adam prophet's story in the Incung manuscript Ini Asan Pulung? The purpose of this study is to understand the narration of Adam prophet's story from the perspective of Kerinci society in past. This study utilized the qualitative method and philological approach. Meanwhile, the text of the manuscript is analyzed using the intertextual approach. The result of this study is known that the story of Adam in the manuscript contains a different narration and plot from other manuscripts. The writer of the manuscript was re-compiled Adam's story from various religious references and added local cultural elements in his story.
\end{abstract}

Keywords: Adam's Story, the Incung Script, Kerinci, Old Manuscript.

\section{ABSTRAK}

Naskah-naskah keagamaan yang ditemukan di Kerinci, umumnya ditulis menggunakan aksara Jawi (Arab-Melayu). Namun, temuan naskah Incung yang menjadi koleksi pusaka Depati Anum Puncak Alam dari Dusun 


\begin{abstract}
Sungai Tutung mengindikasikan sesuatu yang berbeda. Naskah tersebut merupakan naskah keagamaan yang berisi kisah nabi Adam. Naskah Incung ini berjudul Ini Asan Pulung dengan kode EAP117-44-1-6. Permasalahan di dalam kajian ini adalah bagaimana narasi kisah penciptaan Adam di dalam naskah Incung Ini Asan Pulung? Tujuannya adalah untuk memahami narasi kisah Adam menurut pandangan masyarakat Kerinci di masa lalu. Metode yang digunakan di dalam kajian ini adalah metode kualitatif dengan pendekatan filologi. Tahapannya adalah, inventarisasi, deskripsi, transliterasi dan penerjemahan. Sementara itu, teks naskah ini juga ditelaah menggunakan pendekatan intertekstualitas untuk mengetahui unsur-unsur teks lain yang memengaruhi narasi teks. Hasil kajian menunjukkan bahwa kisah Adam di dalam naskah Incung memiliki narasi dan alur yang berbeda dengan kisah Adam di dalam naskah-naskah lain. Penulis naskah menyusun kembali cerita nabi Adam dari berbagai sumber lain yang ia ketahui seperti Hikayat Nur Muhammad, Hikayat Nabi Adam dan Qishash al-Anbiya. Penulis naskah juga menambahkan unsur-unsur lokal di dalam kisah Adam yang disusunnya.
\end{abstract}

Kata kunci: Kerinci, Kisah Adam, Naskah Kuno, Surat Incung.

\title{
PENDAHULUAN
}

Percaya pada nabi dan rasul merupakan salah satu dari enam rukun Iman di dalam ajaran Islam. Kisah-kisah tentang mereka tertulis di dalam teks kitab suci Alquran. Kisah Adam merupakan salah satu di antara kisah para nabi dan rasul yang diceritakan. Kisah penciptaan Adam ini termaktub pada beberapa surah dalam al-Qur'ān seperti pada Surah al-Baqarah ayat 3137, Surah al-Maidah ayat 27, Surah al-A'raf 11-25, Surah alHijr 26-33, Surah al-Isra' ayat 61, Surah Tāāa ayat 115-121, dan Surah Sad ayat 71-76.

Selain di dalam teks al-Qur'ān, kisah Adam disebutkan di dalam hadis serta kitab-kitab keagamaan yang ditulis oleh kalangan ulama. Misalnya di dalam Kitab Qișaș al-Anbiyā yang ditulis oleh Ibnu Kathir dan Kitab Tarikh al-Rusūl wa al-Muluk yang ditulis oleh at-Ṭabari. ${ }^{2}$ Kedua kitab tersebut ditulis menggunakan bahasa dan aksara Arab.

${ }^{1}$ Deddy Ilyas, "Di Balik Kisah Adam as: Menarik Nalar Makna Penciptaan,” Ilmu Agama 15, no. 1 (2016): 111-23.

${ }^{2}$ Ahmad Farhan, "Kitab Qasas al- Anbiyâ pada Bab Ihtijâj Âdam dan Mûsâ Karya Ibnu Katsîr: Analisis Morfosintaksis Terjemahan M. Abdul 
Pada perkembangannya di Indonesia, kisah Adam menjadi sangat populer bagi kalangan umat Islam. Narasi tentang Adam kemudian ditulis ulang dalam berbagai naskah lokal. Di antara naskah tersebut adalah: pertama, Naskah Keislaman dari Skriptorium Merapi-Merbabu Nomor 18 VIIL 7 dan 115L 5. Dua naskah ini ditulis menggunakan aksara Buda dan Bahasa Jawa pada media lontar. ${ }^{3}$ Kedua, Naskah Samud Ibnu Salam. Naskah sastrakeagamaan ini ditemukan di Kebumen, Jawa Tengah. Ditulis menggunakan huruf Arab-Pegon dan bahasa Jawa Tengah Pesisiran. ${ }^{4}$ Ketiga, Naskah Ambiya Pegon koleksi Widyapustaka Pura Pakualaman. Naskah ini ditulis menggunakan huruf Pegon dan bahasa Jawa. ${ }^{5}$

Tidak hanya di Jawa, naskah-naskah lokal yang berisi kisah penciptaan Adam juga ditemukan di Sumatera. Dalam tulisannya, Ahmad Abas Musofa pada tahun 2017 membahas mengenai kisah Nabi Adam yang terdapat dalam naskah Ulu yang berasal dari Bengkulu. Naskah tersebut dinamakan Naskah Asal Mulo Jibarail Menempo Adam dengan kode MNB 07.68. ${ }^{6}$ Musofa juga menyebutkan keberadaan naskah Ulu lain yang mengisahkan hal yang sama yaitu Naskah Bijabarail Nempa Adam (MNB 07. 59). Dua naskah ini ditulis menggunakan

Ghaffar E.M.” (Universitas Islam Negeri Syarif Hidayatullah, 2015), 32-36; Ibnu Rusydi dan Siti Zolehah, "Al-Tabari dan Penulisan Sejarah Islam: Telaah atas kitab Tarikh al-Rusul wa al-Muluk Karya Al-Tabari," al-Afkar, Journal for Islamic Studies 1, no. 2 (2018): 146-47, https://doi.org/10.5281/ zenodo.3554866.

${ }^{3}$ Agung Kriswanto, "Naskah-Naskah Keislaman dari Skriptorium Merapi- Merbabu di Perpustakaan Nasional," Jumantara: Jurnal Manuskrip Nusantara 10, no. 1 (2019): 22,29, https://doi.org/doi.org/10.37014/ jumantara.v10i1.23.

${ }^{4}$ Kamidjan, "Naskah Syamud Ibnu Salam Sebuah Sastra Keagamaan," Jumantara: Jurnal Manuskrip Nusantara 7, no. 1 (2016): 4-5.

${ }^{5}$ Mohammad Sahlan, "Ambiya Pegon Pupuh 16-21: Kisah Nabi Adam (Suntingan Teks dan Terjemahan)" (Universitas Gadjah Mada, 2017).

${ }^{6}$ Ahmad Abas Musofa, "Nabi Adam AS Dalam Historiografi Bengkulu (Kajian Naskah Ulu Atau Ka-Ga-Nga Asal Mulo Jabaril Menempo Adam)," Tsaqofah \& Tarikh 2, no. 1 (2017): 2-3, http://ejournal.iainbengkulu.ac.id/ index.php/twt/article/view/783/691. 
bahasa Serawai di atas gelondong bambu sepanjang 50 dan 52 $\mathrm{cm}$.

Naskah Asal Mulo Jibarail Nempo Adam bercerita tentang proses penempaan ukuran tanah yang akan dijadikan sebagai bakal Adam. ${ }^{7}$ Diceritakan bahwa Jibrail memulai menempa tanah berukuran panjang sepuluh lebar sepuluh akan tetapi usaha Jibrail tidak berhasil. Jibrail kemudian berangsur-angsur mengurangi ukuran tanah tersebut hingga menjadi panjang sedepa-lebar sedepa. Barulah ukuran tanah tersebut dijadikan sebagai bakal Adam. Cerita berlanjut mengenai Jibrail yang menghadap Tuhan untuk memohon agar Adam diberikan nyawa. Tuhan memberikan nyawa Adam berbentuk garam kepada Jibrail dengan syarat tidak boleh dibuka di tengah jalan. Akan tetapi, Jibrail membuka garam tersebut di tengah perjalanan dan mendapati garam tersebut tidak berisi. Jibrail kembali menghadap Tuhan untuk meminta nyawa Adam. Kali ini Jibrail mematuhi perintah Tuhan dengan tidak membukanya di perjalanan. Jibrail kemudian menyuapkan garam tersebut kepada Adam hingga ia bernyawa.

Selain tulisan Ahmad Abas Musofa belum ditemukan peneliti lain yang membahas kisah Adam di dalam naskah beraksara lokal di Sumatera. Lebih dari itu, kajian-kajian naskah beraksara lokal dengan tema keagaamaan secara umum masih minim dilakukan di Sumatera. Padahal sejatinya, kajian terhadap naskah beraksara lokal bertema keagamaan merupakan hal yang menarik untuk dilakukan. Pasalnya sejauh pengamatan, naskah keagamaan yang ada di Nusantara ditulis menggunakan modifikasi dari aksara Arab seperti Aksara Jawi atau Arab-Melayu dan Aksara Pegon. Namun, untuk naskah keagamaan yang ditemukan di Bengkulu, justru ditulis menggunakan Aksara Ulu, yakni turunan dari Aksara Kawi atau Sumatera Kuno. ${ }^{8}$

Di Sumatera sendiri, aksara lokal berkembang di bagian utara maupun selatan. Di bagian utara, aksara lokal digunakan dalam lingkup kebudayaan Batak. Aksara tersebut lazim disebut

${ }^{7}$ Musofa, 3-5.

${ }^{8}$ Uli Kozok, Surat Batak: Sejarah Perkembangan Tulisan Batak (Jakarta: Kepustakaan Populer Gramedia, 2009), 67-69. 
sebagai Surat Batak. ${ }^{9}$ Uli Kozok menyebutkan bahwa Surat Batak memiliki banyak varian seperti varian Angkola-Mandailing, varian Karo, varian Batak Toba dan varian Pak-Pak-Dairi. Secara umum, dokumen kuno beraksara Batak ditulis pada media bambu dan kulit kayu yang disebut lak-lak.

Sementara itu, di bagian Selatan, berkembang aksara lokal yang disebut sebagai aksara Surat Ulu. Surat Ulu ini terbagi lagi menjadi tiga kelompok yaitu Surat Incung, Surat Rencong dan Surat Lampung. ${ }^{10}$ Surat Incung adalah aksara yang berkembang di wilayah Kerinci. Surat Rencong adalah aksara yang digunakan di wilayah Bengkulu dan Sumatera Selatan. Sementara itu, Surat Lampung adalah Surat yang digunakan di wilayah Lampung. Pembagian Surat Ulu ke dalam tiga kelompok, menurut Kozok, masih bersifat sementara karena belum ada batasan jelas terhadap perbedaan ke tiga aksara tersebut.

Surat Incung terdiri atas 28 huruf. Masing-masing huruf terdiri dari huruf konsonan yang diikuti oleh vokal a. Jenis huruf seperti ini lazim disebut sebagai aksara Abugida. ${ }^{11}$ Surat Incung digunakan oleh orang Kerinci di masa lalu untuk menulis berbagai dokumen penting baik berupa naskah maupun inskripsi. Berbagai dokumen tertulis tersebut kemudian diwariskan secara turun temurun sebagai benda pusaka.

Kozok mencatat bahwa naskah yang ditulis menggunakan Surat Incung berisi mengenai ratapan kesedihan, percintaan dan tambo. ${ }^{12}$ Naskah yang berisi ratapan kesedihan dan percintaan umumnya ditulis pada media bambu dan kertas. Sementara naskah yang berisi tambo ditulis pada media tanduk. Akan tetapi, di dalam dua tulisannya, Kozok sama sekali tidak menyinggung adanya manuskrip Incung yang bertema keagamaan. Penelitian yang dilakukan oleh Sunliensyar sebelumnya, juga tidak menyinggung adanya dokumen manuskrip Incung yang bertema keagamaan. Penulis hanya membahas tentang adanya manuskrip

${ }^{9}$ Kozok, 67-68.

${ }^{10}$ Uli Kozok, Kitab Undang-Undang Tanjung Tanah: Naskah Melayu yang Tertua (Jakarta: Yayasan Obor Indonesia, 2006), 52.

${ }^{11}$ Kozok, Surat Batak: Sejarah Perkembangan Tulisan Batak, 67.

${ }^{12}$ Kozok, Kitab Undang-Undang Tanjung Tanah: Naskah Melayu yang Tertua, 37-39. 
Incung yang berisi mantra dan mengandung unsur kosakata Islam di dalamnya. ${ }^{13}$ Misalnya, teks mantra yang mengandung kata "Allah", "Aja Berain","Nabi" dan "Baginda Ali". ${ }^{14}$ Keberadaan unsur Islam di dalam teks Incung juga disinggung oleh Kozok, misalnya penggunaan kata basumamilah atau basamilah pada awal teks. ${ }^{15}$

Kata "basamilah" atau "basumamilah" ini bisa dilihat di dalam naskah bambu milik Rajo Sulah dari Dusun Siulak Mukai dan naskah bambu milik Depati Satio Mandaro dari Rawang. ${ }^{16}$ Di dalam naskah Rajo Sulah berbunyi, "aih basamilah mujur akung mangarang". ${ }^{17}$ Dengan demikian, dapat dikatakan terdapat pengaruh Islam di dalam naskah beraksara Incung meski isinya tidak secara spesifik membahas masalah keagaamaan.

Di Kerinci, naskah yang memuat teks dan masalah keagamaan memang tidak ditulis menggunakan aksara Incung, melainkan menggunakan aksara Arab-Melayu. Naskah itupun berasal dari periode yang jauh belakangan. Misalnya, naskah-naskah keagamaan Kerinci yang ditulis oleh K.H. Burkan Saleh ${ }^{18}$ maupun naskah anonim yang memuat tentang fatwa rokok. ${ }^{19}$

Akan tetapi, temuan salah satu naskah ${ }^{20}$ Incung pada bambu di Kerinci mengindikasikan hal yang berbeda. Isi naskah

${ }^{13}$ Hafiful Hadi Sunliensyar, "Idu Tawa Lam Jampi: Mantra-mantra dalam Naskah Surat Incung Kerinci," Manuskripta 8, no. 1 (2018): 31-35, https://doi.org/10.33656/manuskripta.v8i1.100.

${ }^{14}$ Sunliensyar, 50-51.

${ }^{15}$ Kozok, Kitab Undang-Undang Tanjung Tanah: Naskah Melayu yang Tertua, 37.

${ }^{16}$ Alimin, Sastra Incung Kerinci (Kerinci: Dinas Pariwisata dan Kebudayaan Kabupaten Kerinci, 2003), 31,41.

${ }^{17}$ Wahyu Rizki Andhifani, "Naskah Kuna Pusaka Raja Sulah Desa Siulak Mukai Kerinci Jambi," Siddhayatra 17, no. 2 (2012): 66.

${ }^{18}$ Mhd Rasidin dan Oga Satria, "Tradisi Tulis Menulis Ulama Kerinci: Manuskrip Islam Peninggalan K.H. Muhammad Burkan Saleh (1912-2010)," Lektur Keagamaan 18, no. 2 (2020): 463-88.

${ }^{19}$ Oga Satria, "Fatwa Rokok dalam Manuskrip Kerinci," Penelitian Agama dan Masyarakat (PENAMAS) 33, no. 2 (2020): 277-92.

${ }^{20}$ Jikalau dilihat dari medianya yang keras yaitu bambu, maka dokumen tertulis ini dapat digolongkan sebagai prasasti atau inskripsi (Lihat Naniek Harkantiningsih et al., Metode Penelitian Arkeologi (Jakarta: Pusat Penelitian Arkeologi Nasional, 1999), 194.). Meskipun demikian, peneliti 
tersebut justru bertema keagamaan dengan memuat kisah nabi Adam di dalamnya. Naskah yang dimaksud adalah naskah bambu yang disimpan oleh Depati Anum Muncak Alam dari Dusun Sungai Tutung, Mendapo Kemantan. Naskah ini telah didigitalisasi oleh British Library dengan kode EAP117-44-1-6 dan dapat diakses secara daring melalui https://eap.bl.uk/archive-file/ EAP117- 44-1-6. ${ }^{21}$

Naskah ini sebenarnya telah dialihaksarakan oleh Voorhoeve pada tahun 1941. Namun, hasil alihaksaranya kurang begitu memuaskan sehingga perlu dilakukan pembacaan ulang. Permasalahan yang ingin diungkapkan di dalam kajian ini adalah bagaimana narasi kisah penciptaan Adam di dalam naskah Incung dengan kode EAP117-44-1-6? Tujuannya adalah untuk memahami kisah Adam menurut pandangan masyarakat Kerinci di masa lalu sebagaimana yang tertuang di dalam naskah Incung.

Kajian ini menggunakan metode kualitatif yang dilakukan menggunakan pendekatan filologi. Penelitian filologi pada dasarnya terbagi menjadi dua bagian yakni kodikologi dan tekstologi. ${ }^{22}$ Kodikologi mempelajari bahan naskah seperti kondisi bahan, tinta, media, cap air dan lain sebagainya. Sementara itu, tekstologi mempelajari teks atau isi naskah. Pada kajian ini lebih ditekankan pada teks atau isi naskah.

Tahapan kajian ini adalah: (1) tahapan inventarisasi, yaitu mengumpulkan informasi keberadaan naskah di suatu daerah. Dalam hal ini, inventarisasi dilakukan dengan menelusuri keberadaan naskah bambu dari Kerinci yang telah didigitalisasi dan dimuat di situs Endangered Archives Programme (EAP) milik British Library; (2) tahapan deskripsi, yaitu mendeskripsikan

Belanda sebelumnya, tetap menggolongkan dokumen bambu sebagai naskah. Mereka hanya menambahkan informasi bahan atau media tulis di belakangnya seperti naskah bambu atau naskah tanduk. Pada penelitian ini masih digunakan istilah naskah bambu mengikuti istilah yang digunakan peneliti Belanda. Dengan demikian, perlakuan dokumen ini sebagai objek penelitian masih menggunakan metodologi penelitian naskah dalam ilmu filologi.

${ }^{21}$ Anonim, "Bamboo Manuscript," British Library, n.d., https://eap.bl. uk/archive-file/EAP117-44-1-6.

${ }^{22}$ Siti Baroroh Baried et al., Pengantar Teori Filologi (Jakarta: Departemen Pendidikan dan Kebudayaan, 1985), 55-57. 
bentuk fisik dan teks naskah. Pendeskripsian naskah merujuk pada foto digital dan deskripsi yang tersedia di dalam situs; (3) tahapan alihaksara (transliterasi) yaitu kegiatan penggantian huruf dari aksara Incung ke aksara latin. Tahapan ini menggunakan metode standar. Dengan menggunakan metode ini, peneliti diperkenankan memperbaiki kesalahan-kesalahan teks; ${ }^{23}$ (4) tahapan penerjemahan yaitu, menerjemahan teks dari bahasa Kerinci ke bahasa Indonesia. Tahapan ini menggunakan metode penerjemahan bebas; ${ }^{24}$ (5) tahapan analisis/telaah isi, yaitu menelaah isi teks naskah dan hubungannya dengan teks dalam naskah atau sumber lain yang memiliki kesamaan cerita. Tahapan ini menggunakan pendekatan intertekstual.

\section{HASIL DAN PEMBAHASAN Deskripsi}

Naskah ini didigitalisasi pada tahun 2007 oleh Tim EAP117 dengan kode EAP117/44/1/6. Naskah ini disebutkan sebagai koleksi Depati Anum Muncak Alam dari Desa Sungai Tutung, Kec. Air Hangat Timur, Kab. Kerinci. Penelusuran terhadap katalog naskah-naskah Kerinci, juga menemukan bahwa naskah ini telah dialihaksarakan oleh Voorhoeve di tahun 1941. Voorhoeve memberikan penomoronan Tambo Kerintji (TK) 125 pada naskah tersebut. ${ }^{25}$ Namun demikian, hasil alihaksara Voorhoeve tidak bisa dipahami isinya dikarenakan ia terbatas melakukan alihaksara dengan metode diplomatis.

Naskah ini ditulis pada media bambu sepanjang lima ruas. Masing-masing ruas memiliki panjang sekitar $35 \mathrm{~cm}$ dan diameter $6 \mathrm{~cm}$. Jadi, panjang keseluruhan bambu sekitar $175 \mathrm{~cm}$. Naskah ini ditulis menggunakan aksara Surat Incung dengan teknik gores serta menggunakan bahasa Kerinci. Selain itu, Naskah ini tidak memuat nama penulis serta tidak memuat penanggalan

\footnotetext{
${ }^{23}$ Baried et al., 69.

${ }^{24}$ Ilzamuddin Ma'mur, "Konsep Dasar Penerjemahan: Kajian Teoritis," Al-Qalam 21, no. 102 (2004): 444.

${ }^{25}$ Petrus Voorhoeve et al., "Tambo Kerintji: Disalin dari Toelisan Djawa Koeno, Toelisan Rentjong, dan Toelisan Melayoe jang Terdapat pada Tandoek Kerbaoe, Daoen Lontar, Boeloeh dan Kertas, dan Koelit Kajoe Poesaka Simpanan Orang Kerintji,” 1941, 91-94.
} 
sehingga tidak diketahui usianya secara pasti. Laporan Belanda menunjukkan bahwa tradisi menulis dengan surat Incung masih berlangsung hingga pertengahan abad ke-19 M. ${ }^{26}$ Selanjutnya menurut laporan Westenenk, pada awal abad ke-20 M tidak ditemukan lagi orang Kerinci yang bisa membaca Incung. ${ }^{27}$ Oleh sebab itu, patut diduga bahwa naskah-naskah Incung paling akhir ditulis pada abad ke-19 M.

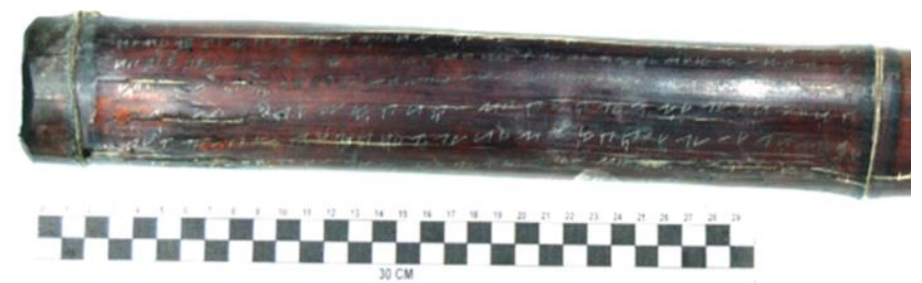

Sumber: https://eap.bl.uk/archive-file/EAP117-44-1-6

\section{Gambar 1.}

Ruas pertama Naskah Bambu Ini Asan Pulung (EAP117/44/1/6)

Kondisi fisik naskah cukup baik. Bambu yang digunakan telah berwarna coklat kehitaman. Teks masih bisa dibaca dari ruas pertama hingga keempat. Sementara itu, pada ruas kelima sebagian besar sudah aus dan rusak. Jumlah baris teks secara keseluruhan adalah 92 baris dengan rincian pada ruas pertama terdapat 16 baris, ruas kedua 1 baris, ruas ketiga 19 baris, ruas keempat 18 baris dan ruas kelima 23 baris. Teks awal pada naskah ini adalah "Ini Asan Pulung" (IAP). Sementara itu, teks akhirnya berbunyi "Sada itu alah pasan aku....". Kisah penciptaan Adam diceritakan dari ruas bambu pertama hingga ketiga sebanyak 40 baris.

\section{Pedoman Alihaksara dan Terjemahan}

Berikut ini adalah tanda yang menjadi pedoman di dalam alihaksara dan terjemahan. Pertama, tanda garis miring (/) menunjukkan pergantian baris. Kedua, tanda dua garis miring (//) menunjukkan pergantian ruas bambu. Ketiga, angka arab pada

26 Petrus Voorhoeve, "Kerintji Documents," Bijdragen tot de Taal-, Land- en Volkenkunde 126, no. (1970): 369-99.

27 L.C. Westenenk, "Rèntjong-schrift. II. Beschreven Hoorns in het Landschap Krintji," in Tijdschrift voor Indische Taal-, Land-, en Volkenkunde 61 (Batavia: Albrecht en co./'s-Gravenhage, M. Nijhoff, 1922), 96-98. 
sisi kanan atas menunjukkan catatan perbaikan. Keempat, tanda kurung siku ([..]) menunjukkan penambahan huruf oleh penulis inskripsi. Kelima, tanda kurung biasa (..) baik pada bagian alihaksara maupun terjemahan menunjukkan penambahan dan rekonstruksi huruf dan frasa oleh peneliti. Keenam, tanda petik pada bagian terjemahan merupakan bagian perkataan dan dialog antar tokoh. Ketujuh, tanda kurung kurawal (\{..\}) menunjukkan penghilangan huruf atau diakritik oleh penulis naskah.

\section{Alihaksara}

Ini asan pulung, sabalun gumi langit ini,/ sabalun bulan bintang ini jadi, sabalun lahin dan batin/ ini jadi. Muka ada Rasuluh Alah dititah akan Alah Hutala itu manjadil akan Gumi Ampat Mandarap, muka ada Jibarain ini mandatang akan/ sambah kapada Sabaanar Alah, muka Alah batitah akan Rasulur Alah muka di-/ urut awaknya muka ada tanah kapada Rasulur Alah mukal dibarikan kapada Jibarain muka diparatiga ulih Ji-/ barain. Muka kata Rasulur Alah tanah di tangan itu Jiba-/ rain ambur ka bawah muka manjadi bumi sapa(ra)ti icay kapas/ Bahu(a)ka(n) sabuwah diambur ka datas manjadi langit. Kata Ra-/sulur Allah, lagi sabuwah itu parabuwat Bumi Ampat Manda(ra)p/[A]jibarain tiyada tahu barabuwat \{Gu\}mi Ampa\{t\} Mandarap muka diliyat Rasulur Alah itu manitik akan ayir/ matanya, muka diambik tanah itu ulih Jibarain muka dibuwat/ Gumi Ampat Mandarap menjadi sapa(ra)ti bayang bayang. Bahuakan muka ba-l titah Jibarain, hir Rasulur Alah apa akan nyawa Adam i-// ni anyah tanay akan jari kanan itu, tapuk kamubun Adam itu. Muka katal Jibarain itu, amba sakali ini maliyat nyawa Alah mu-/ ka diri tiyada tahu kay sungguh jari diri. Muka (di)patapuk akan/ kamubun Adam itu, talakar muka baranyawa anya. Sudah alah iluk/ muka kuwap manyarak mulutnya dibaik muka mangucap Satapirlah./ Sudah kuwap muka sampay baik, muka baasin tapanti kapala baik mangucap/ Lahamndu muka sampay baik.

Muka bajalan Gumi Hampat Mandarap itu saa-/ ntan, muka manyurung gumi langit kita ini manjadi alam basar ini./ Taradiri matahari, bulan dan bintang, umput dan sabuwang dan sandaguri/ sada itu alah dulu jadi. Muka jadi pula Kayu Pulay itu sabap hanya ma-/ njadi aluh Kayu Tuwa itu. Muka batitah Rasulur Alah sasat Adam/ itu, ambuh hanya babini. Muka disasat ulih Jibarain ambuh a$/(n g k a) w$ babini Gumi Hampat Mandarap ini kini, ambuh kata anya. Muka mana sasat/ Rasulur Alah, ini Adam kita satunda baduwa, ini 
jangan kita makan./ Tidak iya Alah iya tuwan aku Rasuluh Alah, aku andak makan juga. Takala a/kaw andak makan, jangan kita satunda apa pamakan makan tan aku ini tuwan al/nyah makan akaw. Takala [a] babuwat makan makan itu imbaw juga aku kata anya. Muka hanya la-/ lu mangirat ka Makah, muka diturut ulih Jibarain basuwa sapaduwan jalan. Mukal manyagih mangacap Rasulu Alah tacanta kapada Adam muka bapasan kapada Jibarain kata a-l kan kapada Adam diri akan mijan iyang duwa di badan Adam itu. Muka diri-l kan mijan iyang duwa ulih Jibarain di badan Adam itu. Itu asan kita ba-/ rasusu. Muka baasin Adam itu tababut tulang usuk anya sabalah manjadi/ parampun muka manjadi laki bini muka baanak urang ampat Sauka, Nabiuka, Saina, Na-/biina .......

\section{Terjemahan}

Inilah asal pulung, sebelum bumi langit ini, sebelum bulan bintang ini jadi, sebelum lahir dan batin ini jadi. Maka ada Rasulullah dititahkan Allah Huta'ala menjadikan Bumi Empat Mendarap. Maka, adalah Jibrail ini mendatangkan sembah kepada Sebenar Allah. Maka, Allah bertitah kepada Rasulullah. Maka dipijat badannya, maka ada tanah pada Rasulullah, maka diberikan kepada Jibrail. Maka dipertiga oleh Jibrail. Maka kata Rasulullah, tanah di tangan itu Jibrail hamburkan ke bawah. Maka menjadi bumi seperti terbangan kapas. Setelah itu, sebuah lagi hamburkan ke atas, menjadi langit. Kata Rasulullah, yang sebuah itu lagi, perbuat Bumi Empat Mandarap. Jibrail tidak tahu membuat Bumi Empat Mendarap. Maka dilihat Rasulullah itu menitikkan air matanya, maka diambil tanah itu oleh Jibrail. Maka dibuat Bumi Empat Mendarap menjadi seperti bayangbayang. Setelah itu, maka bertitah Jibrail, "wahai Rasulullah apa akan nyawa Adam ini?" (Berkata Rasulullah), "ini (nyawa Adam) tanaikan ${ }^{28}$ tangan kanan itu, tepuk ke ubun-ubun Adam". Maka kata Jibrail itu, "hamba sekali ini melihat nyawa (dari) Allah, maka diri tiada tahu sungguh tangan diri". Maka ditepukkan ke ubun-ubun Adam, terpasang maka bernyawalah dia. Sudahlah elok, maka menguap (Adam) membuka mulutnya secara sempurna. Maka mengucap, "Astagfirullah". Setelah selesai menguap sempurna, maka bersin terpelanting kepalanya, mengucap "Alhamdu” sampai sempurna.

${ }^{28}$ Tanai: tatang; tating; membawa (mengangkat) di atas telapak tangan (Anonim, "Tanai," Kamus Besar Bahasa Indonesia, n.d., https://kbbi.web.id/ tanai.) 
Maka berjalan Bumi Empat Mendarap itu sebentang, maka menyorong bumi dan langit kita ini menjadi alam yang besar ini. Terdirilah matahari, bulan dan bintang, rumput, sembuang dan sidaguri. Semua itulah yang dahulu jadi. Maka jadi pula, Pohon Pulai itu, sebab itulah ia menjadi pohon tua. Maka bertitah Rasulullah, "sesat ${ }^{29}$ kepada Adam itu, maukah dia beristri". Maka disesat oleh Jibrail, "maukah engkau beristri Bumi Empat Mendarap ini sekarang? Mau katanya. Maka berbuat sesat Rasulullah, "ini Adam kita beriringan berdua, ini jangan kita makan". (Kata Adam) "Tidak ya Allah, ya tuanku Rasulullah, aku hendak makan juga". (Kata Rasulullah), "tatkala engkau hendak makan, jangan kita beriringan, apa makanmakanan, aku inilah yang punya, ini makanan engkau". "Tatkala berbuat makan-makan itu, panggil juga aku", katanya. Maka, dia (Rasulullah) kemudian pergi ke Mekkah. Kemudian diikuti oleh Jibrail, bersua diperduaan jalan. Maka, memanggil mengucap Rasulullah tercerita kepada Adam, maka berpesanlah (Rasulullah) kepada Jibrail, "katakan kepada Adam, dirikan mejan yang dua pada badan Adam itu". Maka didirikan mejan yang dua oleh Jibrail di badan Adam itu. Itulah asal kita memiliki susu. Maka bersinlah Adam, tercabut tulang rusuknya sebelah, menjadi perempuan. Maka menjadi suami istri, maka memiliki anak empat orang, Sauka, Nabiuka, Saina, Nabiina.....

\section{Ringkasan Isi}

Kisah ini dimulai dari tokoh Jibrail yang bersujud kepada Allah untuk menciptakan Bumi Empat Mendarap dan Adam. Allah kemudian memerintahkan Rasulullah mengabulkan permintaan Jibrail tersebut. Rasulullah kemudian memijat tubuhnya sendiri untuk memenuhi perintah Allah. Melalui pijatan itu muncul tanah dari badan Rasulullah. Tanah tersebut diberikan kepada Jibrail untuk dijadikan sebagai zat penciptaan. Rasulullah memerintahkan Jibrail untuk membagi tanah tersebut menjadi tiga bagian. Satu bagian tanah ditaburkan ke arah bawah. Dari tanah tersebut, tercipta bumi yang bentuknya menyerupai terbangan

${ }^{29}$ Kata sesat di dalam teks ini, tampaknya bukan dalam artian upaya Rasulullah untuk menyesatkan atau upaya memberi petunjuk yang salah kepada Adam. Jikalau dilihat konteks kalimatnya maka kata sesat ini lebih bermakna "peringatan" dan "perintah yang mengandung suatu larangan". 
kapas. Satu bagian tanah kemudian ditaburkan ke arah atas sehingga tercipta langit.

Satu bagian tanah lagi seharusnya digunakan untuk menciptakan Bumi Empat Mendarap. Akan tetapi, Jibrail menyatakan ketidakmampuannya menciptakan Bumi Empat Mendarap dari bagian tanah tersebut. Mendengar Jibrail, Rasullullah meneteskan air matanya. Tanah dari tetesan air mata Rasulllah tersebut kemudian dijadikan oleh Jibrail untuk menciptakan Bumi Empat Mendarap yang wujudnya seperti bayangan.

Penulis naskah Ini Asan Pulung ini tidak menjelaskan dari bagian tanah yang mana Adam diciptakan. Karena cerita selanjutnya langsung pada dialog antara Rasulullah dan Jibrail yang hendak memberikan nyawa kepada tubuh Adam. Jibrail menanyakan tentang apa yang akan dijadikan sebagai nyawa Adam. Rasulullah kemudian memberikan nyawa Adam kepada Jibrail dengan menaruhnya di telapak tangan.

Rasulullah memerintahkan Jibrail untuk menepuk tangan berisi nyawa itu ke ubun-ubun Adam. Jibrail kemudian mengikuti perintah Rasulullah sehingga Adam menjadi sosok yang bernyawa. Ketika tubuhnya bernyawa sempurna, Adam menguap sambil mengucapkan Astagfirullah. Setelah menguap, Adam kemudian bersin sambil mengucapkan Alhamdulillah.

Tokoh yang diciptakan sebelum Adam, yakni Bumi Empat Mendarap kemudian berjalan di sepanjang bumi. Hal tersebut membuat bumi dan langit kemudian berubah menjadi alam yang sangat besar. Dari sanalah tercipta bulan, bintang, matahari, rerumputan, sembuang dan tanaman sidaguri. Teks ini juga menyebutkan perihal pohon Pulai (Alstonia scholaris) sebagai jenis pohon yang paling awal diciptakan.

Kisah berikutnya terkait dengan kemunculan istri Adam. Meskipun pada bagian ini dialog antara tiga tokoh yakni Rasulullah, Adam, dan Jibrail susah dipahami. Namun tampaknya, menceritakan Adam yang mau beristri tetapi Rasulullah memberikan syarat kepada Adam untuk tidak memakan makanan tertentu yang dilarangnya.

Adam kemudian bersikukuh untuk memakan makanan yang dilarang Rasulullah, sehingga membuat Rasulullah meninggalkannya. Rasulullah pergi menuju Mekkah yang kemudian 
disusul oleh Jibrail. Ketika di pertengahan jalan, Jibrail berjumpa dengan Rasulullah. Pada perjumpaan tersebut, Rasulullah memerintahkan Jibrail untuk mendirikan dua mejan (tugu batu) di tubuh Adam. Jibrail menunaikan perintah Rasulullah tersebut, pendirian dua mejan di tubuh Adam menyebabkan manusia sekarang ini memiliki organ susu.

Setelah Jibrail mendirikan mejan di tubuh Adam, Adam kemudian bersin yang menyebabkan sebilah tulang rusuknya tercabut. Tulang rusuk Adam menjadi sosok perempuan. Adam kemudian memperistri sosok perempuan tersebut dan memiliki empat orang anak yaitu Sauka, Nabiuka, Saina, Nabiina.

\section{Telaah Isi}

Naskah ini memiliki teks awal yang berbunyi "Ini Asan Pulung" yang diartikan sebagai ini asal pulung. Berdasarkan hal tersebut, tampaknya naskah ini tidak ditujukan secara khusus untuk membahas kisah Adam. Akan tetapi asal usul "pulung" yang berkaitan pula dengan kisah Adam.

Arti kata pulung di dalam naskah ini masih belum terungkap. Jika diasumsikan kata pulung sama dengan kata polong dalam bahasa Melayu, maka pulung dalam hal ini berarti hantu atau roh jahat yang suka mengganggu orang (menyebabkan penyakit dan sebagainya). ${ }^{30}$ Namun demikian, kata pulung yang dimuat dalam teks ruas keempat justru berhubungan dengan bunyi mantra untuk menghindari pengaruh dari roh jahat.

Naskah ini menyebutkan beberapa nama tokoh yang sangat terkait dengan kepercayaan Islam. Nama dan tokoh yang disebutkan antara lain: (1) Alah yang berasal dari kata Allah; (2) Rasuluh Alah atau Rasulur Alah yang berasal dari kata Rasulullah; (3) Jibarain yang berasal dari kata Jibrail atau Jibrail serta; (4) kata Adam. Tokoh lain yang disebutkan adalah istri Adam, Bumi Empat Mendarap serta empat orang anak Adam yaitu Sauka, Nabiuka, Saina, dan Nabiina.

${ }^{30}$ Salah satu arti polong dalam KBBI adalah hantu atau roh jahat yang suka mengganggu orang (menyebabkan penyakit dan sebagainya) (Anonim, "Polong,” Kamus Besar Bahasa Indonesia, n.d., https://kbbi.web.id/polong.) 
Peran Rasulullah di dalam kisah Adam naskah Ini Asan Pulung (IAP), lebih ditonjolkan daripada peran Allah itu sendiri. Rasulullah diceritakan sebagai tokoh yang pertama kali diciptakan Allah Huta'ala serta tokoh yang berperan dalam penciptaan langit, bumi, Bumi Empat Mendarap dan Adam. Keberadaan tokoh Rasulullah yang mendahului proses penciptaan Adam, bahkan yang memberikan nyawa kepada Adam, sangat erat kaitannya dengan narasi dan pemahaman Sufistik tentang konsep Nur Muhammad. ${ }^{31}$

Konsep ini meyakini bahwa Nur Muhammad adalah makhluk paling awal yang diciptakan oleh Allah sebelum alam semesta ini diciptakan. Lebih lanjut disebutkan, bahwa konsep Nur Muhammad meyakini bahwa Nur Muhammad adalah asal roh segala Nabi dan dari Nur Muhammad itu pula alam semesta dan isinya diciptakan. ${ }^{32}$

Konsep Nur Muhammad dalam konteks Nusantara, ditulis dalam manuskrip klasik yang berjudul Hikayat Nur Muhammad. Hikayat ini sangat populer dan ditemukan beberapa salinannya di Indonesia. Salah satu manuskrip yang paling tua adalah Hikayat Nur Muhammad yang ditulis oleh Syekh Syamsuddin Al-Banjari pada tahun $1668 \mathrm{M}^{33}$

Di dalam teks Incung Ini Asan Pulung, dikisahkan bahwa ketika nyawa masuk ke dalam Adam. Adam kemudian menguap dan bersin. Ketika Adam bersin, ia kemudian mengucapkan kalimat "alhamdu". Kisah semacam ini, juga terdapat di dalam teks kitab Qishas al-Anbiyā. Di dalam kitab tersebut, dikisahkan ketika nyawa ditiupkan Allah dari bagian kepala Adam, maka Adam kemudian bersin. Lalu Adam mengucapkan kalimat "alhamdulillah" setelah diajarkan para malaikat. ${ }^{34}$

${ }^{31}$ Achmad Achmad dan M. Muhtarom Ilyas, "Faham Ulama Hadist dan Sufi Terhadap Keyakinan Tentang Nur Muhammad," Sosial Humaniora 8, no. 1 (2015): 69-76.

${ }^{32}$ Achmad dan Ilyas, 70-73; Zulfa Jamalie, "Syekh Ahmad Syamsuddin Al-Banjari dan Kitab Hikayat Nur Muhammad," in Annual International Conference on Islamic Studies (AICIS), 2014, 4.

${ }^{33}$ Jamalie, 3.

${ }^{34}$ Musofa, "Nabi Adam AS dalam Historiografi Bengkulu (Kajian Naskah Ulu atau Ka-Ga-Nga Asal Mulo Jabaril Menempo Adam),” 13. 
Teks Incung menceritakan bahwa penciptaan langit dan bumi terjadi sebelum penciptaan Adam. Latar waktu yang sama juga dijumpai di dalam Hikayat Nabi Adam. ${ }^{35}$ Misalnya pada teks halaman 1 yang berbunyi:

"Maka adalah sebelum menjadikan Nabi Adam Alaihi Salam, (Allah) menjadikan langit dan bumi dan di antara keduanya dengan firman Allah yang berbunyi..." 36

Selain itu, teks Incung menyebutkan bahwa bumi dan langit sama-sama tercipta dari tanah. Hal ini bertolak belakang dengan Hikayat Nabi Adam, yang menyebutkan bahwa langit dan bumi diciptakan dari air dan buih. Sebagaimana teks hikayat yang berbunyi:

"Maka Allah Bisubhanahuwa Taala menjadikan ia akan menghabiskan air itu pun berasap dan berubah. Syahadan daripada itulah dijadikan langit dan daripada buih itulah dijadikan bumi ....." 37

Narasi lain yang menarik untuk didedah adalah adanya larangan untuk memakan makanan tertentu. Hal ini dapat dilihat di dalam teks naskah ruas ke 2 yang berisi dialog antara Rasulullah dan Adam. Kata Rasulullah di dalam teks "ini Adam kita beriringan selama ini, ini jangan kita makan.” Teks naskah Incung mengisyaratkan adanya larangan dari Rasulullah kepada Adam untuk memakan suatu makanan tanpa sepengetahuannya. Hal tersebut merupakan persyaratan bagi Adam bila hendak beristri dan bila ingin tetap bersamanya. Namun, Adam diceritakan melanggar larangan tersebut. Seperti yang diucapkan Adam, "tidak ya Allah, ya Tuanku Rasulullah, aku hendak makan juga."

Larangan untuk memakan makanan tertentu bagi Adam, sebenarnya juga dikisahkan di dalam al-Qur'an meskipun dengan alur dan narasi yang jauh berbeda. Di dalam Alqur'an, dise-

${ }^{35}$ Nurul Nasuha Binti Mohd. Rosle dan Zubir Bin Idris, "Hikayat Nabi Adam: Satu Kajian Teks dan Analisis Berdasarkan Pengkaedahan Keagamaan," Wacana Sarjana 2, no. 2 (2018): 1-15.

${ }^{36}$ Rosle dan Idris, 5-6.

${ }^{37}$ Rosle dan Idris, 6. 
butkan bahwa Allah memerintahkan Adam dan istrinya untuk menjauhi sebuah pohon dan melarang memakan buahnya. Seperti di dalam Surah al-Baqarah ayat 35 yang terjemahannya sebagai berikut:

"Dan Kami berfirman: Hai Adam! Tinggallah engkau dan isterimu di dalam surga ini, dan makanla dengan nikmat (berbagai makanan) yang ada disana sesukamu. (Tetapi) janganlah kamu dekati pohon ini, nanti kamu termasuk orang-orang yang zalim." 38

Ayat al-Quran ini mengisyaratkan latar waktu perintah larangan mendekati pohon tersebut adalah setelah istri Adam diciptakan. Akan tetapi, di dalam teks Incung justru diceritakan bahwa latar waktunya adalah sebelum istri Adam diciptakan.

Perbedaan lain yang cukup menonjol antara naskah Incung Ini Asan Pulung dengan naskah lain adalah mengenai anak keturunan Adam. Di dalam kitab Qishas al-Anbiyā disebutkan bahwa jumlah anak Adam adalah 40 orang yang masing-masing lahir berpasangan (kembar). ${ }^{39} \mathrm{Di}$ antara yang paling banyak diceritakan adalah empat anak Adam yang bernama Habil, Qabil, Labuda dan Iklima. Teks Incung juga menyebutkan empat orang anak Adam tersebut. Akan tetapi, mereka memiliki nama yang jauh berlainan yaitu Sauka, Nabiuka, Saina, dan Nabiina.

Meskipun dijumpai perbedaaan, teks incung sejatinya juga memiliki persamaan narasi dengan sumber lain. Misalnya, narasi tentang istri Adam yang diciptakan dari tulang rusuk Adam. Seperti teks yang berbunyi "Muka baasin Adam itu tababut tulang usuk anya sabalah manjadi parampun muka manjadi laki bini," (Maka bersin Adam itu, tercabut tulang rusuknya yang sebelah menjadi perempuan. Maka menjadi suami-istri).

Menurut Halimah Basri, pendapat yang menerangkan bahwa Hawa-istri Adam-berasal dari tulang rusuk Adam

${ }^{38}$ Anonim, "Surah al-Baqarah: 35," Qur'an Kemenag, n.d., https:// quran.kemenag.go.id/sura/2/35.

${ }^{39}$ Musofa, "Nabi Adam AS dalam Historiografi Bengkulu (Kajian Naskah Ulu atau Ka-Ga-Nga Asal Mulo Jabaril Menempo Adam)," 13-14. 
berasal dari penafsiran ulama-ulama klasik. ${ }^{40}$ Di antaranya alȚabary di dalam kitab jami' al-bayan fi tafsir al-Qur'an dan Ibnu Kathir di dalam kitab tafsir al-Qur'an al-Azim. Lebih lanjut Basri menyebutkan bahwa al-Ṭabary mendasari argumennya tersebut dari beberapa hadith. Salah satunya berbunyi:

"Diriwayatkan dari Musa bin Harun berkata:"Saya diberitahukan oleh "Amr bin Hammad dari Asbath dari alSa'd. Ketika Tuhan menempatkan Adam di surga, ia hidup berjalan sendirian tanpa didampingi pasangan. Suatu ketika, Adam tidur, ia bermimpi di samping kepalanya duduk seorang perempuan yang Allah ciptakan dari tulang rusuknya. Adam bertanya: Siapa anda? Dijawab: aku seorang perempua. Adam bertanya lagi. Untuk apa anda diciptakan? Dijawab: supaya tinggal bersamaku." ${ }^{1}$

Berdasarkan uraian di atas, tampak bahwa penulis naskah Ini Asan Pulung menyusun kembali kisah Adam dari berbagai sumber lain yang ia ketahui. Hal ini terlihat jelas dari beberapa unsur cerita di dalam naskah. Pertama, cerita Rasulullah sebagai makhluk yang mendahului segala proses penciptaan terkait erat dengan konsep Nur Muhammad di dalam ajaran Sufistik. Kedua, unsur cerita Adam yang mengucapkan kalimat "alhamdulillah" setelah dimasukkan nyawa ke dalam tubuhnya. Kisah hampir serupa juga terdapat di dalam kitab Qișaș al-Anbiya. Ketiga, unsur larangan bagi Adam untuk memakan makanan tertentu. Cerita larangan terhadap ini terdapat di dalam teks al-Qur'an, kitab Qișaș Al-anbiya dan Hikayat Nabi Adam meskipun dengan alur cerita yang berbeda. Keempat, unsur yang menceritakan bahwa istri Adam berasal dari tulang rusuk Adam. Cerita ini bersumber dari penafsiran ulama-ulama klasik terhadap asal-usul Hawa sebagai istri Adam.

Penulis naskah tampaknya juga menambahkan cerita yang sangat erat kaitannya dengan unsur lokal di Kerinci. Sehingga secara keseluruhan kisah Adam di dalam naskah Incung Ini Asan

${ }^{40}$ Halimah Basri, "Penciptaan wanita," Studi Gender \& Anak 5, no. 1 (2010): 191.

${ }^{41}$ Basri, 191.

600 | https://jlka.kemenag.go.id/index.php/lektur 
Pulung sangat berbeda dengan kisah Adam dari sumber lain. Unsur lokal tersebut akan dibahas pada subbab berikut.

\section{Unsur Lokal di dalam Kisah Adam}

Naskah Ulu Asal Mulo Jibarail Nempo Adam adalah salah satu contoh bagaimana penggalan kisah Adam diadaptasi dalam bentuk lokal. Kisah adaptasi ini, sejauh penelusuran kepustakaan, tidak memiliki persamaan cerita dengan kisah Adam dalam manuskrip lain. Di dalam naskah Asal Mulo Jibarail Nempo Adam, narasi difokuskan proses penempaan tanah oleh Jibrail hingga sesuai ukuran untuk bakal Adam. ${ }^{42}$ Unsur lokal lain di dalam naskah ini adalah, nyawa Adam yang berwujud seperti garam. Garam tersebut disuapkan ke dalam mulut Adam hingga ia bernyawa. Hal ini berbeda dengan kisah Adam dalam kitab Qișaș al-Anbiya yang menceritakan bahwa proses pemberian nyawa Adam adalah dengan tiupan ruh melalui kepala. ${ }^{43}$

Seperti halnya naskah Ulu, unsur lokal juga terdapat pada naskah Incung Ini Asan Pulung. Unsur yang pertama bisa dilihat dari kata maupun kalimat dalam bahasa Arab yang ditulis sesuai dengan pengucapan lokal di Kerinci. Unsur tersebut terlihat dari penamaan tokoh, misalnya, kata "Allah" ditulis menjadi "Alah", Rasuluh Alah atau Rasulur Alah ditulis menjadi Rasulullah serta kata "Jibril" atau "Jibrail" yang ditulis menjadi "Jibarain". Selain itu, terlihat pula dari kata "Astaqfirullah" ditulis menjadi "satapirlah" dan kata "Alhamdu" yang ditulis menjadi "laham ndu".

Penambahan tokoh lain bernama Bumi Empat Mendarap termasuk unsur lokal yang membedakan kisah Adam dari sumber lain. Diceritakan di dalam teks Incung, bahwa Bumi Empat Mendarap diciptakan sebelum Adam. Ia diciptakan dari tanah yang ditetesi air mata Rasulullah. Bumi Empat Mendarap sendiri adalah makhluk yang disebut menyerupai bayangan dan bisa berjalan layaknya manusia seperti teks berbunyi: “...muka dibuwat manjadi Gumi Ampat Mandarap saparati bayang

${ }^{42}$ Musofa, "Nabi Adam AS dalam Historiografi Bengkulu (Kajian Naskah Ulu atau Ka-Ga-Nga Asal Mulo Jabaril Menempo Adam)," 3-5.

${ }^{43}$ Musofa, 13. 
bayang.." (maka dibuatlah menjadi Bumi Empat Mendarap seperti bayang-bayang) (baris ke 14-15), "... muka bajalan Gumi Ampat Mandarap itu saantang." (maka berjalan Bumi Empat Mendarap itu sebentang (baris 23-24).

Proses pemberian nyawa kepada Adam di dalam naskah Incung ini sangat berlainan pula dengan teks di naskah Ulu maupun di dalam kitab Qișaș al-Anbiya. Di dalam kitab Qișaș al-Anbiya, diceritakan bahwa Allah meniupkan nyawa/ruh Adam melalui tiupan di kepala. Sementara itu, di dalam naskah Ulu diceritakan bahwa pemberian nyawa Adam berasal dari Allah dan diberikan melalui perantara Jibrail dengan menyuapi Adam dari mulut. Berbeda lagi dengan naskah Incung yang menceritakan bahwa Adam diberi nyawa oleh Rasulullah melalui perantara Jibril dengan cara menepuk bagian ubun-ubun Adam dengan tangan kanan.

Unsur lain yang sarat dengan unsur lokal Kerinci adalah cerita pendirian dua mejan pada tubuh Adam. Mijan atau mejan sendiri dalam budaya Kerinci adalah tugu-tugu batu yang didirikan di tempat yang dianggap sakral. ${ }^{44}$ Biasanya, tugu batu tersebut berbentuk lonjong maupun silinder. Di dalam teks, diceritakan bahwa Jibrail diperintahkan oleh Rasulullah untuk mendirikan dua mejan di tubuh Adam. Pendirian dua mejan tersebut dianggap sebagai asal-muasal manusia memiliki organ susu (payudara) di bagian dada. Sebagaimana bunyi teks "Muka dirikan mijan iyang duwa ulih Jibarain di badan Adam itu. Itu asan kita barasusu" (baris 36-38) (Maka didirikanlah mejan yang dua oleh Jibrail di badan Adam itu. Itulah asal kita memiliki susu).

Unsur lokal bisa juga ditelusuri dari kepercayaan adanya tanaman yang dianggap sebagai tanaman yang pertamakali diciptakan. Teks Incung ini, menceritakan bahwa rumput dan sembuang, jenis tanaman perdu sidaguri dan pohon pulai sebagai

${ }^{44}$ Hafiful Hadi Sunliensyar, "Asosiasi Gundukan Tanah, Sungai, dan Menhir di Pusat Wilayah Adat Tanah Sekudung, Baratlaut Lembah Kerinci, Dataran Tinggi Jambi (Kajian Fenomenologi)," AMERTA Jurnal Pengembangan dan Penelitian Arkeologi 36, no. 2 (2018): 119, https://doi.org/ 10.24832/amt.v36i2.115-131. 
jenis tanaman yang pertama kali muncul setelah bumi dan langit membesar menjadi alam yang sangat luas.

Berdasarkan uraian di atas, dapatlah ditarik kesimpulan bahwa unsur-unsur lokal yang terdapat pada kisah Adam di dalam naskah Incung Ini Asan Pulung adalah sebagai berikut: pertama, penulisan unsur bahasa Arab menurut pelafalan lokal. Kedua, adanya tokoh lain yang bernama Bumi Empat Mendarap. Ketiga, proses pemberian nyawa Adam dari Rasulullah melalui perantara Jibrail dengan cara menepuk bagian ubun-ubun Adam. Keempat, adanya narasi pendirian mijan (tugu batu) di tubuh Adam yang menyebabkan manusia memiliki organ payudara. Terakhir, unsur kepercayaan adanya tanaman-tanaman yang dianggap sebagai tanaman yang paling awal diciptakan.

\section{PENUTUP}

Naskah Incung yang berjudul Ini Asan Pulung (IAP) merupakan salah satu naskah pusaka milik Depati Anum Muncak Alam dari Dusun Sungai Tutung. Teks Incung ini menceritakan kisah Adam dengan latar dan alur yang sangat berbeda dari sumber lain. Di dalam naskah ini, diceritakan bahwa Adam diciptakan oleh Rasulullah melalui perintah Allah. Rasulullah memberikan nyawa Adam melalui Jibrail dengan cara menepuk bagian ubun-ubun Adam. Teks Incung ini juga menceritakan adanya larangan bagi Adam untuk memakan makanan tertentu. Akan tetapi, larangan tersebut terjadi sebelum istri Adam diciptakan. Istri Adam menurut teks Incung ini diceritakan tercipta dari tulang rusuk Adam ketika ia bersin.

Penulis naskah Incung ini, mungkin sekali menyusun ulang kisah Adam berdasarkan kisah Adam dari berbagai sumber. Beberapa karya yang menginspirasi penulis naskah adalah Hikayat Nur Muhammad, Hikayat Nabi Adam dan cerita Adam dari kitab Qișaș al-Anbiyā. Penulis naskah juga menambahkan unsur lokal Kerinci di dalam kisah Adam yang ia buat. Di antaranya: (1) penulisan nama tokoh dan kalimat dalam bahasa Arab mengikuti ejaan dan pelafalan orang Kerinci; (2) penambahan tokoh lain yang mungkin berakar dari kepercayaan lokal masyarakat yaitu Bumi Empat Mendarap; (3) nyawa Adam yang dimasukkan melalui tepukan di bagian ubun-ubun; (4) 
cerita munculnya bagian organ susu pada manusia karena perintah mendirikan dua mijan di tubuh Adam; dan (5) penamaan empat orang anak Adam menurut penamaan lokal.

\section{UCAPAN TERIMA KASIH}

Penulis mengucapkan terima kasih yang sebesar-besarnya kepada pihak British Library yang telah menyediakan data digital naskah Kerinci secara bebas untuk umum. Ketersediaan data tersebut, sangat membantu dan menambah semangat para peneliti yang berminat mengkaji naskah-naskah kuno di Kerinci. Penulis juga mengucapkan kepada semua pihak yang telah membantu dalam perbaikan dan penerbitan artikel ini.

\section{DAFTAR PUSTAKA}

\section{Buku}

Alimin. Sastra Incung Kerinci. Kerinci: Dinas Pariwisata dan Kebudayaan Kabupaten Kerinci, 2003.

Baried, Siti Baroroh, Siti Chamamah Soeratno, Sawoe Sawoe, Sulastin Sutrisno, dan Moh Syakir. Pengantar Teori Filologi. Jakarta: Departemen Pendidikan dan Kebudayaan, 1985.

Harkantiningsih, Naniek, Bagyo Prasetyo, Yusmaini Eriawati, Aryandini Novita, Nurul Laili, dan Truman Simanjuntak. Metode Penelitian Arkeologi. Jakarta: Pusat Penelitian Arkeologi Nasional, 1999.

Kozok, Uli. Kitab Undang-Undang Tanjung Tanah: Naskah Melayu yang Tertua. Jakarta: Yayasan Obor Indonesia, 2006.

_. Surat Batak: Sejarah Perkembangan Tulisan Batak. Jakarta: Kepustakaan Populer Gramedia, 2009.

Westenenk, L.C. "Rèntjong-schrift. II. Beschreven Hoorns in het Landschap Krintji." In Tijdschrift voor Indische Taal-, Land-, en Volkenkunde 61. Batavia: Albrecht en co./'s-Gravenhage, M. Nijhoff, 1922.

\section{Jurnal Ilmiah}

Achmad, Achmad, dan M. Muhtarom Ilyas. "Faham Ulama Hadist dan Sufi Terhadap Keyakinan Tentang Nur Muhammad." Sosial Humaniora 8, no. 1 (2015): 69-76.

Andhifani, Wahyu Rizki. "Naskah Kuna Pusaka Raja Sulah Desa 
Siulak Mukai Kerinci Jambi.” Siddhayatra 17, no. 2 (2012): 6268.

Basri, Halimah. "Penciptaan Wanita." Studi Gender \& Anak 5, no. 1 (2010): 168-98.

Ilyas, Deddy. "Di Balik Kisah Adam as: Menarik Nalar Makna Penciptaan." Ilmu Agama 15, no. 1 (2016): 111-23.

Kamidjan. "Naskah Syamud Ibnu Salam Sebuah Sastra Keagamaan." Jumantara: Jurnal Manuskrip Nusantara 7, no. 1 (2016): 1-18.

Kriswanto, Agung. "Naskah-Naskah Keislaman dari Skriptorium Merapi- Merbabu di Perpustakaan Nasional." Jumantara: Jurnal Manuskrip Nusantara 10, no. 1 (2019): 19-41.

https://doi.org/doi.org/10.37014/jumantara.v10i1.23.

Ma'mur, Ilzamuddin. "Konsep Dasar Penerjemahan: Kajian Teoritis." Al-Qalam 21, no. 102 (2004): 431-58.

Musofa, Ahmad Abas. "Nabi Adam AS dalam Historiografi Bengkulu (Kajian Naskah Ulu atau Ka-Ga-Nga Asal Mulo Jabaril Menempo Adam)." Tsaqofah \& Tarikh 2, no. 1 (2017): 14.

http://ejournal.iainbengkulu.ac.id/index.php/twt/article/view/783/691.

Rasidin, Mhd, dan Oga Satria. "Tradisi Tulis Menulis Ulama Kerinci: Manuskrip Islam Peninggalan K.H. Muhammad Burkan Saleh (1912-2010)." Lektur Keagamaan 18, no. 2 (2020): 463-88.

Rosle, Nurul Nasuha Binti Mohd., dan Zubir Bin Idris. "Hikayat Nabi Adam: Satu Kajian Teks dan Analisis Berdasarkan Pengkaedahan Keagamaan." Wacana Sarjana 2, no. 2 (2018): 1-15.

Rusydi, Ibnu, dan Siti Zolehah. "Al-Tabari dan Penulisan Sejarah Islam : Telaah atas kitab Tarikh al-Rusul wa al-Muluk Karya AlTabari." al-Afkar, Journal for Islamic Studies 1, no. 2 (2018): 142-59.

https://doi.org/10.5281/zenodo.3554866.

Satria, Oga. "Fatwa Rokok dalam Manuskrip Kerinci." Penelitian Agama dan Masyarakat (PENAMAS) 33, no. 2 (2020): 277-92.

Sunliensyar, Hafiful Hadi. "Asosiasi Gundukan Tanah, Sungai, dan Menhir di Pusat Wilayah Adat Tanah Sekudung, Baratlaut Lembah Kerinci, Dataran Tinggi Jambi (Kajian Fenomenologi)." AMERTA Jurnal Pengembangan dan Penelitian Arkeologi 36, no. 2 (2018): 115.

https://doi.org/10.24832/amt.v36i2.115-131. 
—. "Idu Tawa Lam Jampi: Mantra-mantra dalam Naskah Surat Incung Kerinci." Manuskripta 8, no. 1 (2018): 31-35.

https://doi.org/10.33656/manuskripta.v8i1.100.

Voorhoeve, Petrus. "Kerintji Documents." Bijdragen tot de Taal-, Land- en Volkenkunde 126, no. (1970): 369-99.

\section{Makalah}

Jamalie, Zulfa. "Syekh Ahmad Syamsuddin Al-Banjari dan Kitab Hikayat Nur Muhammad." In Annual International Conference on Islamic Studies (AICIS), 21-24, 2014.

Voorhoeve, Petrus, R.Ng.Dr Poerbatjaraka, H. Veldkamp, M.C.J Voorhoeve, Bernelot Moens, dan Abdul Hamid. "Tambo Kerintji: Disalin dari Toelisan Djawa Koeno, Toelisan Rentjong, dan Toelisan Melayoe jang Terdapat pada Tandoek Kerbaoe, Daoen Lontar, Boeloeh dan Kertas, dan Koelit Kajoe Poesaka Simpanan Orang Kerintji," 1941.

\section{Skripsi}

Farhan, Ahmad. "Kitab Qasas al- Anbiyâ pada Bab Ihtijâj Âdam dan Mûsâ Karya Ibnu Katsîr: Analisis Morfosintaksis Terjemahan M. Abdul Ghaffar E.M." Universitas Islam Negeri Syarif Hidayatullah, 2015.

Sahlan, Mohammad. "Ambiya Pegon Pupuh 16-21: Kisah Nabi Adam (Suntingan Teks dan Terjemahan)." Universitas Gadjah Mada, 2017.

\section{Website}

Anonim. "Bamboo Manuscript." British Library, n.d. https://eap.bl.uk/ archive- file/EAP117-44-1-6.

_. "Polong." Kamus Besar Bahasa Indonesia, n.d. https://kbbi. web.id/polong.

- "Surah al-Baqarah : 35." Qur'an Kemenag, n.d. https://quran. kemenag.go.id/sura/2/35.

. "Tanai." Kamus Besar Bahasa Indonesia, n.d. https://kbbi. web.id/ tanai. 